\title{
Multivariate approach in eucalyptus breeding and its effecton genotype $x$ environment interactions
}

\author{
O.P. dos Santos ${ }^{1}$, I. R. Carvalho ${ }^{2}$, V. J. Szareski ${ }^{2}$, A. J. de Pelegrin ${ }^{1}$, \\ M. H. Barbosa ${ }^{1}$, F. Lautenchleger ${ }^{3}$, G. G. Conte ${ }^{1}$, J. R. Pimentel ${ }^{2}$,

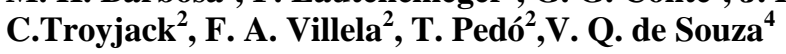 \\ 1 Centro de Genômica e Fitomelhoramento, Universidade Federal de \\ Pelotas, CapãodoLeão, RS, Brasil \\ 2 Centro Tecnológico dePlantas de Lavoura, Universidade Federal de \\ Pelotas, Capão do Leão, RS, Brasil \\ 3 Departamento Agronomia, Universidade Estadual de Maringá, Maringá, \\ PR, Brasil \\ 4 Universidade Federal do Pampa, São Gabriel, RS, Brasil \\ Corresponding author: I.R. Carvalho \\ E-mail: carvalho.irc@gmail.com
}

Genet. Mol. Res. 17 (3): gmr18025

Received May 15, 2018

Accepted July 26, 2018

Published August 14, 2018

DOI http://dx.doi.org/10.4238/gmr18025

ABSTRACT. In view of the need to obtain genetically superior
eucalyptus clones that promote productivity coupled with quality, we
used multivariate statistical techniques for the selection and
evaluation of Eucalyptus spp. clones for wood production. The
experiments were carried out in three environments in the districts of
Eldorado do Sul, Butiá and São Gabriel. A clone of the commercial
species Eucalyptus saligna was used as a common control in all
trials. A total of 84 eucalyptus clones were used belonging to the
breeding program in Rio Grande do Sul, Brazil, in a randomized
block design, with 20 replicates and one plant per plot, spacing $3.50 \mathrm{x}$
$2.14 \mathrm{~m}$. Silvicultural practices were performed according to the
particularities required by each environment. The clones were
evaluated at 36 months for diameter at breast height, total height,
total individual volume with bark and survival of clones. The
datawere submitted to a joint analysis of variance, and the 
significance was interpreted by the $\mathrm{F}$ test at $5 \%$ probability. Interaction tests were performed and then multivariate models were used. Selection of clones from their values of genetic divergence and heterogeneity in relation to the others can be used to increase variability in breeding populations. Improvement strategies such as Intrapopulation Recurrent Selection can be "fed" from selections made based on these parameters, but also focusing on increasing productivity and improving wood technology. There wasa great difference in behavior of the clones for each environment, demonstrating the influence of genotype x environment interactions, which can be evaluated later in amplified clonal tests or in the observation plantings of these clones; these will serve for the future indication of genotypes for commercial plantations.

Key words: Eucalyptus breeding; variability genetic; differential effects of the variation factors

\section{INTRODUCTION}

The genus Eucalyptus belongs to the family Myrtaceae, originating in Australia, where it comprises more than 600 different species. In Brazil, eucalyptus plantations occupy 5.7 million hectares of planted trees and are mainly located in Minas Gerais(24\%), São Paulo (17\%) and MatoGrosso do Sul (15\%) states. There was anincrease of $2.4 \%$ in the area of eucalyptus planted in the last five years in this country. The state of MatoGrosso doSul led this growth, registering an increase of 400 thousand hectares in this period, with an average growth rate of $13 \%$ per year (Ibá, 2017). Eucalyptus is the main cropresponsible for placing the country among the world's largest producers of cellulose.

IncreasesinEucalyptus productivity are mainly due to genetic improvement through the production of intra and interspecific hybrids, naturally or controlled through cloning (Fonseca et al., 2010; Rosado et al., 2012).Clonal Eucalyptus planting areas have expanded throughout the country, due to the ease of the multiplication processes, the possibility of avoiding heterogeneity in the forest plantations, as well an increasein the homogeneity of the technological properties of the wood, making it more suitable for industry.

Before the final recommendation of a clone, it undergoes a series of evaluations in different growing environments (Sudaricet al., 2005). This is necessary, due to environmental diversity in the different growing environments, resulting in phenotypic variation of genotypes, through the genotype and environment (GxE) interactions (Carvalho et al., 2016; Szareski et al., 2017; Santos et al., 2018;). Selection of genotypes with high productivity, adaptability and stability is an important alternative to minimize the effects of theseGxE interactions (Kehl et al., 2016; Szareski et al., 2016; Nardino et al., 2016).

In order to evaluate the physical, chemical, mechanical and anatomical properties of wood, multivariate analyses are widely employedin structural analyses of forests in phytosociological studies (Assiset al., 2012; Lima et al., 2011; Lobãoet al., 2011; Protásioet al., 2012; Trugilho et al., 2003). Analysis of canonical variables, grouping methods and main components are among the multivariate techniques most widely used by researchers.Analysis of canonical variables is one of the most suitable multivariate 
techniques forsituations in whichmany dependent and independent characters of one or more genotypes are analyzed, allowing the analysis of the structure of linear relationships between two groups or character sets formed by metric variables, in order to maximize the correlation between them (Protásio et al., 2012; Hair Junior et al., 2009; Carvalho et al., 2016; Pelegrin et al., 2017).

The optimization method proposed by Tocherstratifiesgenotypes into groups, using a single criterion to maintain intra-group mean distance lower than any intergroup distance (Cruz et al., 2012). The method proposed by Sing (1981) makes it possible to quantify the relative contribution of the characters through genetic distance analyses.

Dissimilarity measures have been proposed for the quantification of distances among genotypes. The generalized distance of Mahalanobis is widely used when experiments with replicates are available (Simon et al., 2012). This is different from the other techniques because it takes into account the correlations among the characters evaluated (Cruz et al.,2012).

In view of the need to obtain genetically superior eucalyptus clones that promote productivity coupled with quality, we used multivariate statistical techniquesfor the selection and evaluation of Eucalyptus spp. clones for wood production.

\section{MATERIAL AND METHODS}

\section{Growing environments}

The experiments were carried outin three environments in the districts of Eldorado do Sul, Butiá and São Gabriel (Table 1). A clone of the commercial species Eucalyptus saligna was usedas a common control in all trials.

\begin{tabular}{|c|c|c|c|}
\hline Municipalities & Eldorado do Sul & Butiá & São Gabriel \\
\hline Geographicalcoordinates & $30^{\circ} 06^{\prime} 89^{\prime \prime} \mathrm{S}$ e $51^{\circ} 44^{\prime} 70^{\prime \prime} \mathrm{W}$ & $30^{\circ} 27^{\prime} 50^{\prime \prime} \mathrm{S}$ e $52^{\circ} 10^{\prime} 05^{\prime \prime} \mathrm{W}$ & $30^{\circ} 44^{\prime} 70^{\prime \prime} \mathrm{S}$ e $54^{\circ} 53^{\prime} 42^{\prime \prime} \mathrm{W}$ \\
\hline Altitude (meters) & 75 & 188 & 139 \\
\hline Previousoccupation & Forest & Forest & Nativefield \\
\hline Soiltype & Gleysolic dystrophic yellow red argisol & Typical dystrophic yellow red argisol & Typicaldystrophicgrayishargisol \\
\hline Averagetemperature $\left({ }^{0} \mathrm{C}\right)$ & 18.2 & 18.2 & 202 \\
\hline Frostrisk & Low & Low & High \\
\hline Relativehumidity $(\%)$ & 82.2 & 82.2 & 72.4 \\
\hline Annualrainfall $(\mathrm{mm})$ & 1570 & 1570 & 1965 \\
\hline
\end{tabular}

\section{Experimental conditions and genotypes used}

A total of 84 eucalyptus clones were used (Table 2) belonging to the breeding program in Rio Grande do Sul, Brazil, in a randomized block design, with 20 replicates and one plant per plot, spacing $3.50 \times 2.14 \mathrm{~m}$. Silvicultural practices were performed according to the particularities required by each environment.

The clones were evaluated at 36 months for diameter at breast height $(\mathrm{DBH}, \mathrm{cm})$, total height $(\mathrm{H}, \mathrm{m})$, total individual volume with bark $\left(\mathrm{VOL}, \mathrm{m}^{3}\right)$ and survival of clones. The total individual volume with bark was calculated using the expression: $\mathrm{VOL}=$ $0.004761+0.000033 \times \mathrm{DBH}^{2} \times \mathrm{H}^{2}$. 
Table 2.Description of the 84 Eucalyptusclones evaluated in the three environments and their respective species/crosses.

\begin{tabular}{|c|c|c|}
\hline NUMBER & SPECIES/HYBRID & NUMBER OF CLONES \\
\hline 1 & E. (grandis $\mathrm{x}$ urophylla) $\mathrm{x}$ not informed & 31 \\
\hline 2 & E.urophylla $\mathrm{x}$ E. globulus & 21 \\
\hline 3 & E. (grandis $\mathrm{x}$ urophylla $) \times$ E.globulus & 12 \\
\hline 4 & E.salignax not informed & 4 \\
\hline 5 & E. (grandis $\times$ urophylla $) \times E .($ urophylla $\times$ globulus $)$ & 3 \\
\hline 6 & E. (grandis $\mathrm{x}$ daligna $) \mathrm{x}$ notinformed & 2 \\
\hline 7 & E.grandis $\mathrm{x}$ E.globulus & 2 \\
\hline 8 & E. (grandis $\mathrm{x}$ urophylla) $\mathrm{x}$ E.maidenii & 2 \\
\hline 9 & E. $($ Grandis $\mathrm{x}$ urophylla $) \times$ E.viminalis & 2 \\
\hline 10 & E.urophylla $\mathrm{x}$ not informed & 1 \\
\hline 11 & E. (dunnii $\times$ grandis $) \times$ E. (urophylla $\times$ globulus $)$ & 1 \\
\hline 12 & E. (dunnii $\mathrm{x}$ grandis $) \times$ E.viminalis & 1 \\
\hline 13 & E.Saligna & 1 \\
\hline 14 & E. $($ dunnii $\mathrm{x}$ grandis $) \times \mathrm{n}$ not informed & 1 \\
\hline TOTAL & & 84 \\
\hline
\end{tabular}

\section{Statistical analysis}

After obtaining the data, they were submitted to a joint analysis of variance, and the significance was interpreted by the F test at $5 \%$ of probability. Afterwards, the Shapiro-Wilk test for normality proposed in 1965 , based on the W statistic was performed. In order to verify the homoscedasticity of the data, the Hartley test was applied. Interaction tests were performed and then multivariate models were used. All statistical procedures were performed using the Genes software (Cruz, 2013).

\section{RESULTS AND DISCUSSION}

The analysis of variance revealed interaction, environment $\mathrm{x}$ clone, for all variables, diameter at breast height (DBH), plant height (PH) and volume of wood (VOM) (Table 3).The contribution of the interaction for the phenotypic manifestation, for the variable diameter at breast height, was $21.3 \%$; among the variation factors, the environmental parameter contributed $13.5 \%$, and clone $34.5 \%$. For wood volume, the contribution of the interaction was $18.1 \%$, the environment $24.4 \%$ and clone $28.4 \%$. For these two variables the greatest contributions werein the clone variation source, demonstrating the relevance of this parameter for these variables. For the plant height variable the greatest contribution was expressed in the environment parameter, $35.2 \%$. The interaction contributed with $15.4 \%$ and the clone variation factor, $14.9 \%$.

Table 3.Summary of analysis of variance for diameter at breast height (DBH), plant height (PH) and wood volume (VOM)

\begin{tabular}{ccccc}
\hline VF & DF & \multicolumn{3}{c}{ Mean Square } \\
\cline { 3 - 5 } & & DBH & PH & VOM \\
\hline Environment (A) & 2 & $3864.89^{*}$ & $261.66^{*}$ & $93.36^{*}$ \\
Clone (B) & 83 & $224.90^{*}$ & $0.07^{*}$ \\
A x B & 166 & $74.01^{*}$ & $49.43^{*}$ & $0.02^{*}$ \\
Block (A) & 57 & $9.80^{*}$ & $12.59^{*}$ & $0.0039^{*}$ \\
Residue & 3552 & 6.49 & 7.01 & 0.0025 \\
\hline CV(\%) & & 18.74 & 17.37 & 41.31 \\
$\mathrm{R}^{2}$ & & 0.63 & 0.60 & 0.65 \\
\hline
\end{tabular}

* Significant at $5 \%$ by the $\mathrm{F}$ test.

Regarding the coefficient of variation, the results found (18.7\%), work evaluating eucalyptus clones; they found $21.57 \%$ for the variable diameter at breast height. Plant height (PH) showed a coefficient of $17.37 \%$, a result superior to those described by Trugilho et al. 
(2001) (11.4\%), working with clones, Rosado et al. (2010) (7.45\%) studying E. urophylla, and Freitas et al. (2009) with E. urograndis (9.1\%). The volume of wood (VOM) (41.31\%) showed lower coefficient and similar to the studies conducted by Trugilho et al. (2001).

The use of multivariate analyses aims to show the similarity among the treatments, through the use of the association among the variables, in order to form groups and to demonstrate the contribution of each character to the differentiation of the genotypes. Dismemberment of the multivariate analysis by environment allows one to reveal the behavior of the clones in each environment separately.

From Table 4, it is possible to identify that, for the variable diameter at breast height (DBH), both Eldorado do Sul and São Gabriel locations obtained seven classes, where the $15 \mathrm{~cm}$ measurement was the most frequent. These values indicate the good performance of the clones, since more than $50 \%$ of the clones hadvalues equal or superior to $15 \mathrm{~cm}$. On the other hand, the Butiá environment presented a greater number of classes (eight), obtaining a lower magnitude of the values for this variable, where $12.75 \mathrm{~cm}$ was the most frequent measure. Also, for the variable plant height $(\mathrm{PH})$, the environments differed inthe number of classes, where Eldorado do Sul presented eight classes, Butiá seven classes and São Gabriel nine classes, and also inthe magnitude of the classes, where the most frequent measurements in the environments of Eldorado do Sul, Butiá and São Gabriel were 18.75, 13, and $16.5 \mathrm{~cm}$ respectively.

Table 4.Results for the grouping of 84 Eucalyptus genotypes in three environments, using the Tocher optimization method, based on standardized mean Euclidean distance.

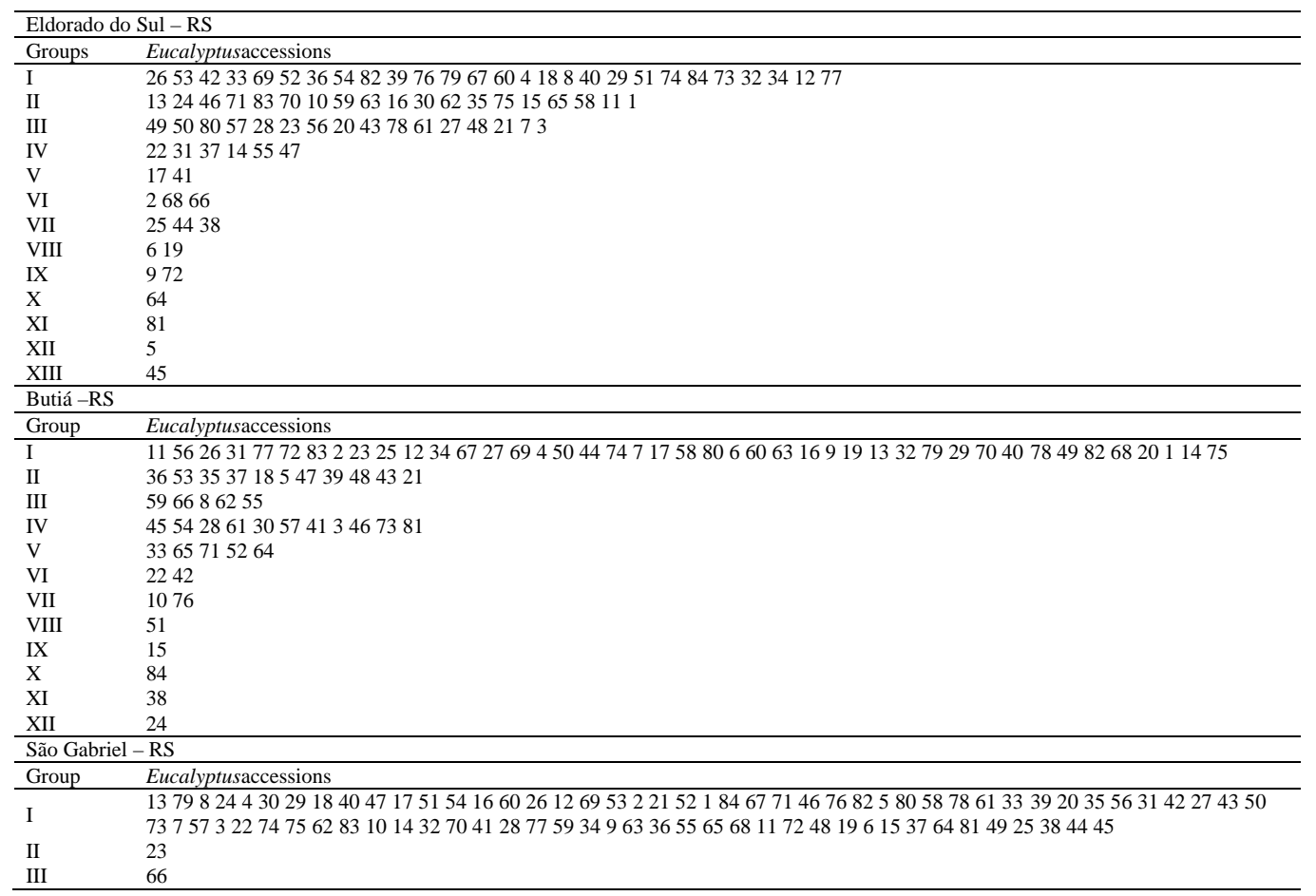

The distribution of frequencies of the phenotypic classes, shown in Figure 1, reveals that Butiá was the environment that contributed the most to the dissimilarity of the variables diameter at breast height and plant height, with $77.79 \%$ and $9.49 \%$, respectively. For the wood 
volume variable, the Eldorado do Sul environment had the largest contribution to distinguish it with $39.54 \%$, followed by the São Gabriel environment with $28.93 \%$.

There were groupings of the genotypes by the Tocher optimization method (Table 4), where, for the Eldorado do Sul environment, 13 groups were formed. Group I was composed of 27 accessions, with approximately $32 \%$ of the individuals, group II with 19 accessions (22\%) and group III with 16 accessions (19\%), totaling $73 \%$ of the individuals; these values indicate that there is great intragroup homogeneity. Also, $27 \%$ of the remaining individuals were distributed in 10 groups, where group IV was formed by six accessions, groups VI and VII constituted by three accessions, and groups V, VIII and IX composed by two accessions. Groups X, XI, XII, XIII were composed of only one accession each, which, according to Vasconcelos et al. (2007) indicates high divergence among clones for this environment. This divergence is of great importance for the work of the breeder, since it allows its exploration for the future development of cultivars.
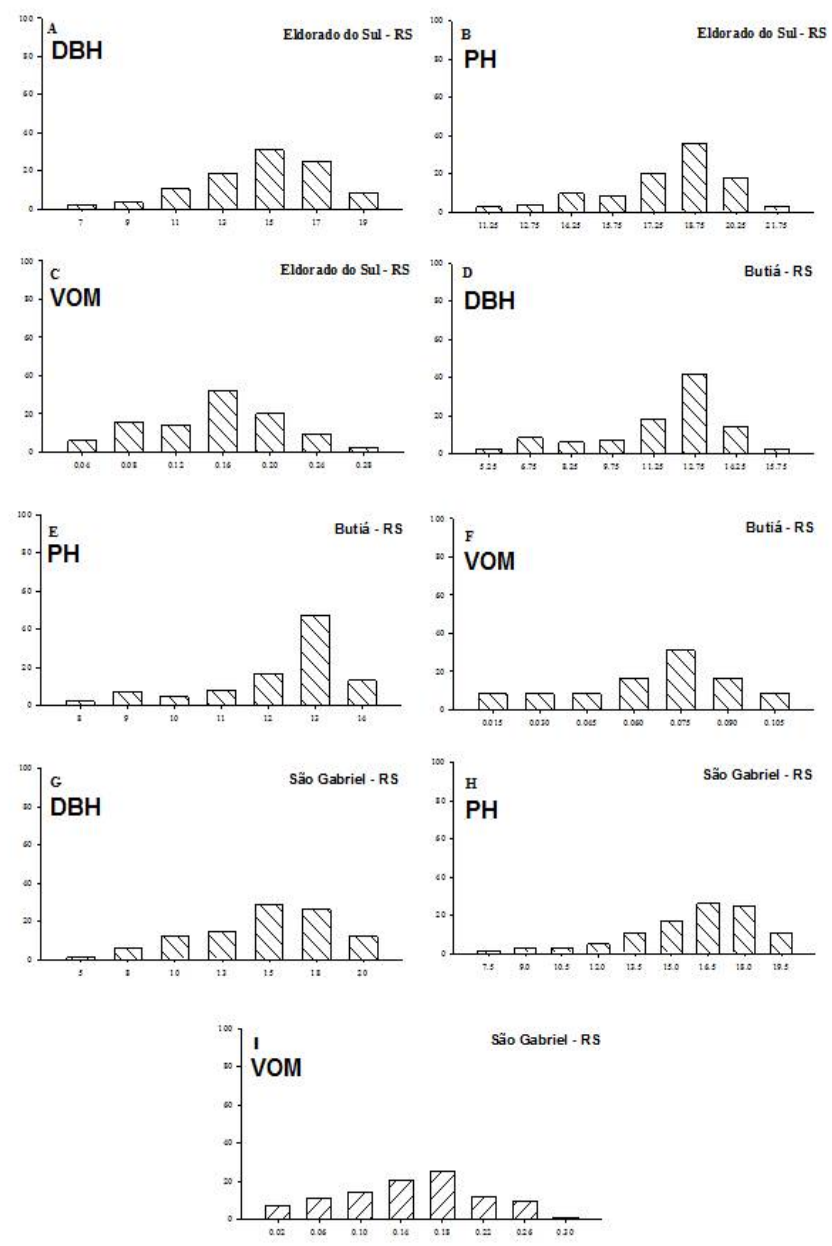

Figure 1.Frequency distribution of phenotype classes for diameter at breast height (DBH), plant height $(\mathrm{PH})$ and wood volume (VOM) in São Gabriel - RS, Eldorado do Sul - RS and Butiá - RS environments. 


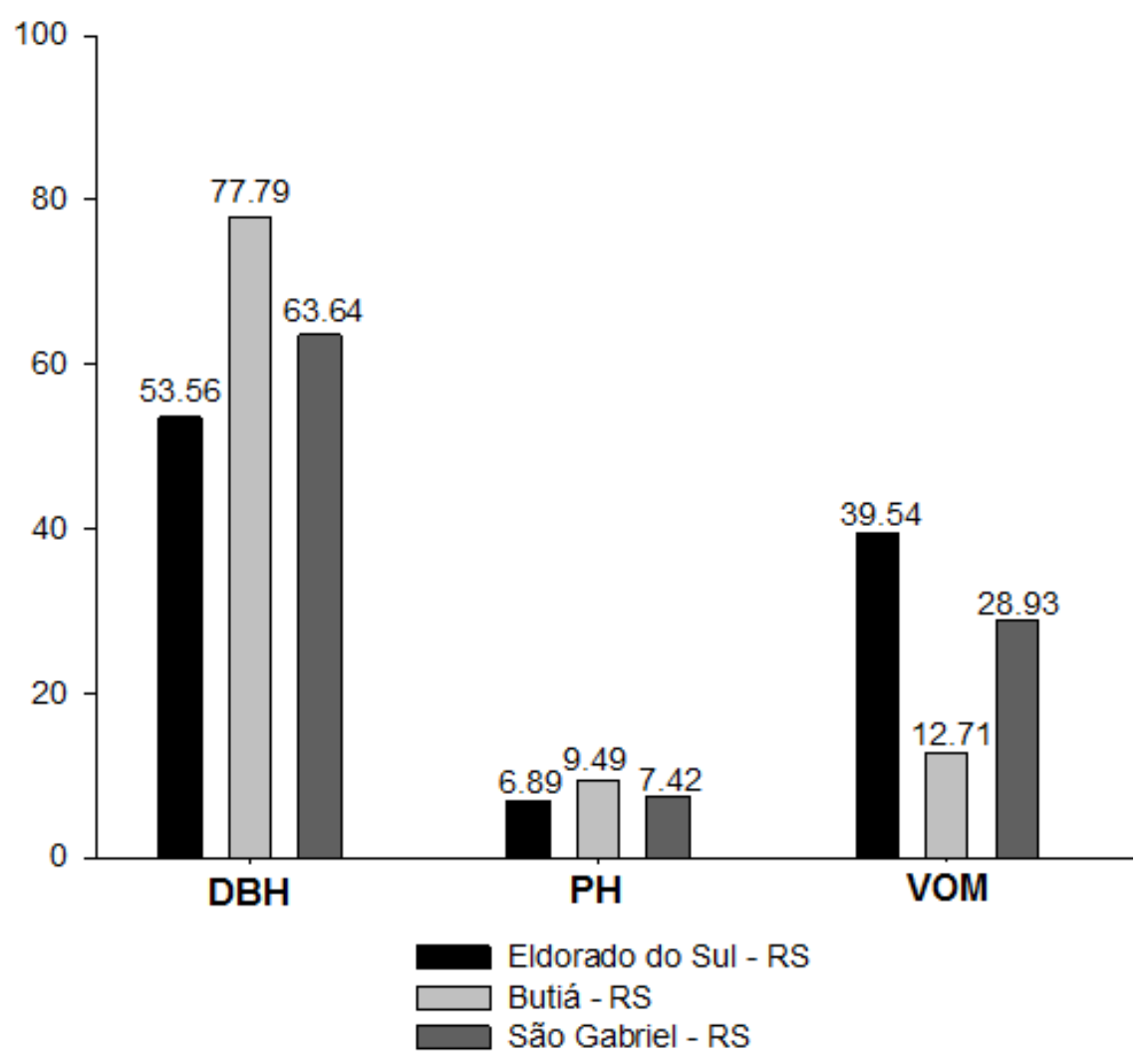

Figure 2.Frequency distribution of phenotype classes for diameter at breast height (DBH), plant height (PH) and wood volume (VOM).

The Butiá environment revealed grouping results similar to Eldorado do Sul, presenting the formation of 12 groups. Among the groupings, the group I was the largest, composed of 43 accessions with $51.2 \%$ of the individuals. Groups II and IV were composed of 11 accessions each, groups III and V hadfive accessions each, groups VI and VII hadtwo accessions each. The remaining groups (VIII, IX, X, XI and XII) were composed of clones with higher dissimilarities, where each accession formed a specific group. The results found for these two environments coincide with a study by Caixeta et al. (2003) onEucalyptus clones, where the authors analyzed 44 clones, which formed 11 different groups. On the other hand, the São Gabriel environment had less influence on the dissimilarity of the clones, having grouped them into only three groups, and group I was composed of 82 accessions or $97.6 \%$ of the individuals. The other two groups had only one accession each.

Through the dendrograms, it is possible to perceive the genetic divergence among the 84 Eucalyptus clones, where the most dissimilar clones for the Eldorado do Sul environment were genotypes 26 and 45 (Figure 3). In the Butiá environment, the largest distances were found for clones 11 and 76 (Figure 4) and, for the São Gabriel environment, clones 13 and 66 (Figure 5). 


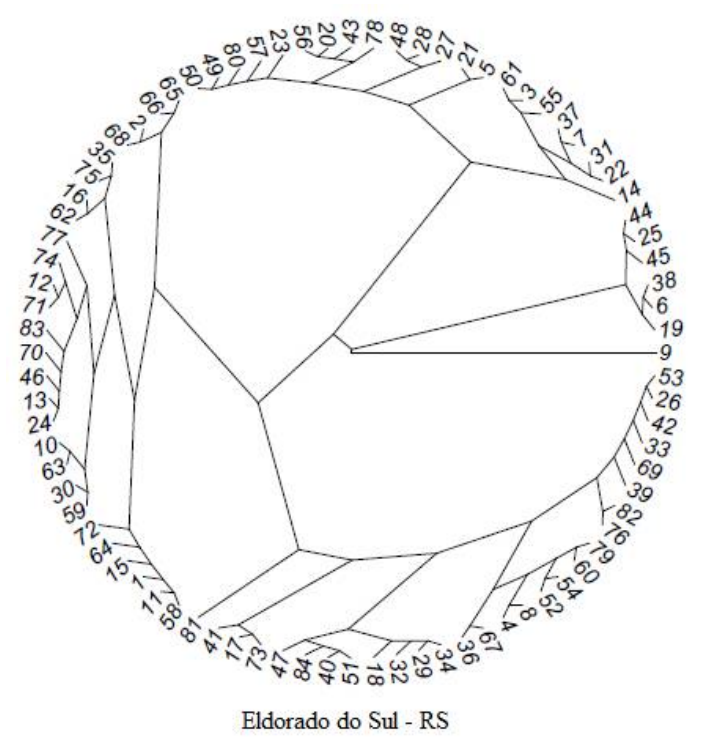

Figure 3.Dendrogram with genetic divergence in 84 Eucalyptus genotypes in Environment 1, using normalized Euclidean distance, obtained by the nearest neighbor method.

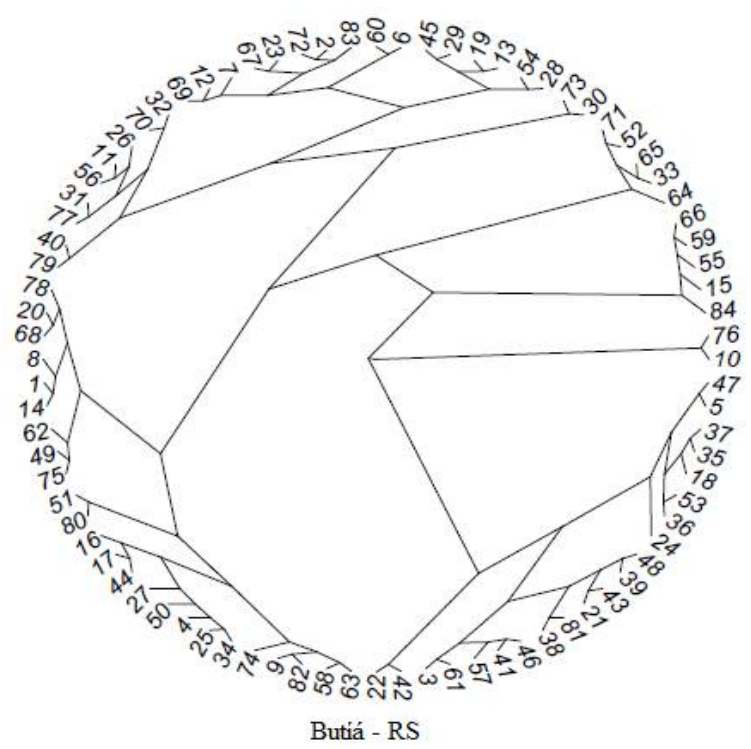

Figure 4.Dendrogram with genetic divergence in 84 Eucalyptus genotypes in Environment 2, using normalized Euclidean distance, obtained by the nearest neighbor method. 


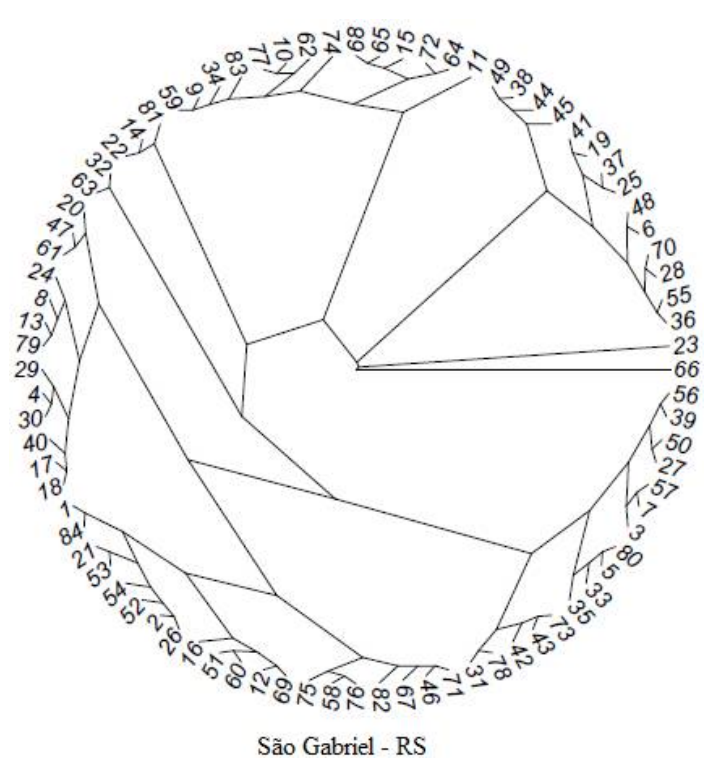

Figure 5.Dendrogram with genetic divergence in 84 Eucalyptus genotypes in Environment 3, using normalized Euclidean distance, obtained by the nearest neighbor method.

The behavior of the clones in each growing environment was compared (Figure 6). Clones that disaggregate from the others indicate greater genetic variability, thus, for the Eldorado do Sul environment, fourgroups can be distinguished, clones being clustered distinctly: clones 45, 44 and 25, clones 38,6 and 19, clones 72 and 9, and the remainder of the clones clustered. Also, for the Butiá environment, there was a similar behavior of clones 22 and 24, these forming a group. Two other groups can be identified, one of which is formed by clones 76 and 10, and the other by clones 55 and 16. The São Gabriel environment had clone 66 demonstrating great variability, forming a group. Two other groups varied from the others, the first one being formed by clones 23 and 45 and the second by clones 25 and 81 . Clones highlighted in distinct groups are the ones that most contribute to the interaction between genotype and environment (GXE).

Figure 5 represents the graphical dispersion in the two-dimensional space of the 85 clones under study, using the first and second canonical variables. The groups formed by means of the graphic dispersion of the scales show that in the São Gabriel environment, clone 66 was the most dissimilar among the clones, following the same tendency of the groups found by the Tocheroptimization method and normalized Euclidean distance, thus reinforcing the findingobtained by the different multivariate techniques for this environment. However, for the other environments the results obtained by the different tests were not concordant, where for the Eldorado do Sul environment, from the graphic dispersion of canonical variables it was possible to identify a more dissimilar group of clones 6, 19, 25, 38, 44 and 48, and for the Butiá environment a group with clones 76 and 10 (Figure 6). 

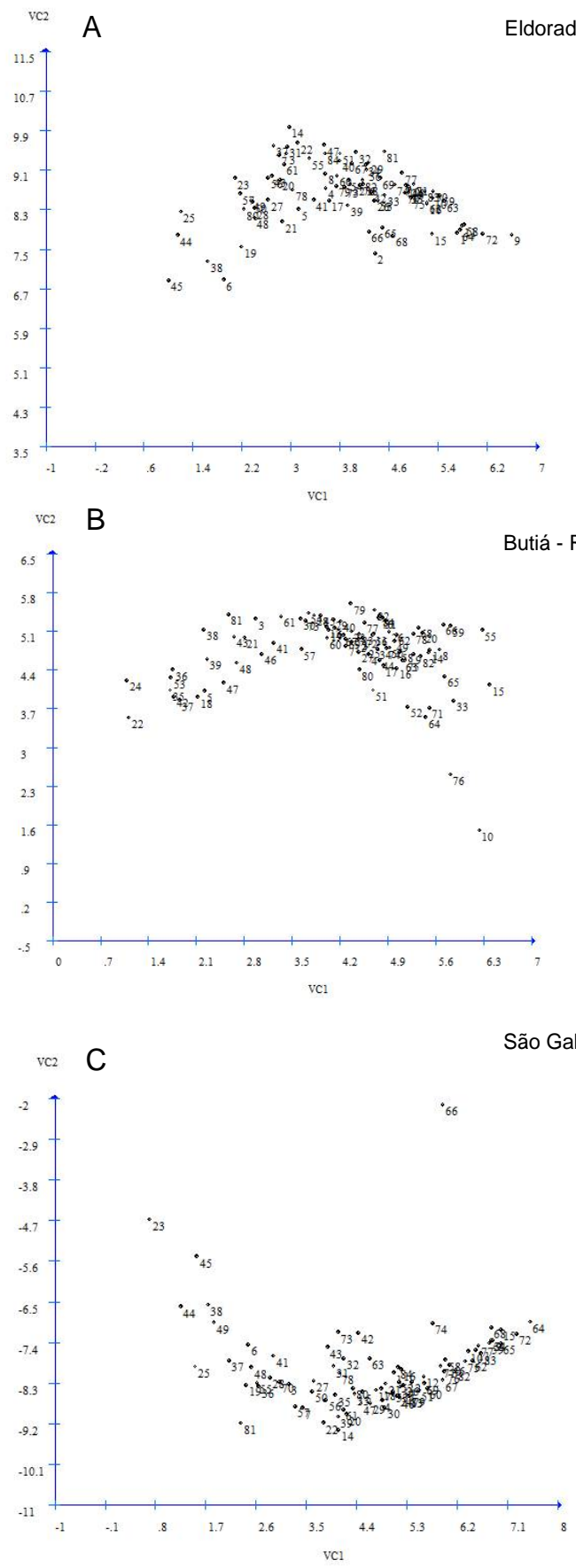

Figure 6.Dispersion graph of 85 Eucalyptus clones in relation to the scores of the first two canonical variables (VC1 and VC2) for the environments of Eldorado do Sul - RS (A), Butiá (B) and São Gabriel (C). 
The selection of clones from their values of genetic divergence and heterogeneity in relation to the others can be used to increase variability in breeding populations. Improvement strategies such as the Intrapopulation Recurrent Selection can be "fed" from selections made based on these parameters, but also focusing on increasing productivity and improving wood technology.

There is a great difference in behavior of the clones for each environment, demonstrating the influence of the genotype $\mathrm{x}$ environment interaction, which can be evaluated later in the clonal tests amplified or in the observation plantings of these clones; thesewill serve for the future indication of genotypes for the commercial plantations.

\section{CONFLICTS OF INTEREST}

The authors declare no conflict of interest.

\section{REFERENCES}

Assis MR, Protásio TP, Assis CO, Trugilho, PF, et al. (2012).Qualidade e rendimentos do carvão vegetal de um clone híbrido de Eucalyptus grandis $\mathrm{x}$ Eucalyptus urophylla. Pesq.Agrop. Bras.32: 291-302. https://doi.org/10.4336/2012.pfb.32.71.291

Caixeta RP, Truguilho PF, Rosado SCS, Lima JT. (2003).Propriedades e classificação da madeira aplicadas à seleção de genótipos de Eucalyptus. Rev. Árvore. 27:43-51. http://dx.doi.org/10.1590/S0100-67622003000100006

Carvalho IR., Nardino M, Demari, GH, Bahry CA, et al. (2016).Bisegmented regression, factor analysis and AMMI applied to the analysis of adaptability and stability of soybean. AJCS.: 14101416.https://doi.org/10.21475/ajcs.2016.10.10.pne63

Carvalho IR., Nardino M,Pelegrin AJ, Ferrari M, et al. (2016).Path analysis and Annicchiarico method applied in relation to protein in corn grains. AJBAS 10:300-306.

Cruz CD, Regazzi, AJ, Carneiro PCS.(2012). Modelos biométricos aplicados ao melhoramento genético.Viçosa: Editora UFV, $514 \mathrm{p}$.

Cruz CD. (2013). GENES - A software package for analysis in experimental statistics and quantitative genetics. Acta Sci.Agron. 35: 271-276.Doi: 10.4025/actasciagron.v35i3.21251

Fonseca SM, Resende MDV, Alfenas AC, Guimarães LMS, et al. (2010). Manual prático de melhoramento genético do eucalipto. Viçosa: UFV. 200p.

Freitas RGD, Vasconcelos ESD, Cruz CD, Rosado AM, et al. (2009).Predição de ganhos genéticos emprogênies de polinizaçãoaberta de Eucalyptus urograndis cultivadas em diferentes ambientes e submetidas a diferentes procedimentos de seleção. Rev. Árvore.33: 255-263 http://dx.doi.org/10.1590/S0100-67622009000200007

Hair JF, Black WC, Babin BJ, Anderson RE, et al. (2009). Análise multivariada de dados. Porto Alegre: Bookman. 688p.

Lima EA, Silva HD, Lavoranti OJ.(2011).Caracterização dendroenergética de árvores de Eucalyptusbenthamii.Pesq.Flor. Bras, 31:09-17.

Kehl K,Kehl K, Szareski VJ, Carvalho IR, et al. (2016).Genotype environment interaction under industrial and physiological quality of wheat seeds.IJCR8: 38461-38468.

Lobão MS, Castro VR, Rangel A, Sarto C, et al. (2011).Agrupamento de espécies florestais por análises univariadas e multivariadas das características anatômica, física e química das suas madeiras. Sci.For. 39:469-477.

Nardino M,Carvalho IR,Follmann DN,Pelegrin AJ, et al. (2016). Genetic breeding backround and sustainability in environments of production: A review. IJCR. 8: 39629-39632.

Pelegrin AJ, Carvalho IR, Nunes ACP, Demari GH, et al.(2017). Adaptability, stability and multivariate selection by mixed models. AJPS. 17:3324-3337.https://doi.org/10.4236/ajps.2017.813224

Protásio TP, Tonoli GHD,Guimarães JM, Bufalino L, et al (2012).Correlações canônicas entre as características químicas e energéticas de resíduos lignocelulósicos. Rev. Cerne. 18:433-439. http://dx.doi.org/10.1590/S010477602012000300010

Rosado AM, Rosado TB, Alves AA, Laviola BG, et al. (2012). Seleção simultânea de clones de eucalipto de acordo com produtividade, estabilidade e adaptabilidade. Pesq.Agrop.Bras.47: 966-973. http://dx.doi.org/10.1590/S0100204X2012000700013

Rosado AM, Rosado TB, Júnior MFRR, Bhering LL, et al. (2010). Ganhos genéticos preditos por diferentes métodos de seleçãoemprogênies de Eucalyptusurophylla.Pesq.Agrop.Bras. 44: 1653-1659. http://dx.doi.org/10.1590/S0100$\underline{204 X 2009001200014}$ 
Santos OP, Carvalho IR,Nardino M,Olivoto T, et al. (2018). Methods of adaptability and stability applied to Eucalyptus breeding. Pesq.Agrop.Bras. 53: 53-62. http://dx.doi.org/10.1590/s0100-204x2018000100006

Shapiro SS andWilk MB.(1965). An Analysis of Variance Test for Normality (Complete Samples).Biometrika. 52: 591609.

Sudaric A, Simic D and Vrataric M. (2005). Characterization of genotype by environment interactions in soybean breeding programmes of southeast Europe. Plant Breeding, 125: 191-194.

Szareski VJ, Carvalho IR, Nardino M, Demari GH, et al.(2016). Phenotype stability of soybean genotypes for characters related to the physiological quality of seeds produced under different environmental conditions. AJBAS 10: 279289.

Szareski VJ, Carvalho IR, Kehl K, Levien AM, et al. (2017). Univariate, multivariate techniques and mixed models applied to the adaptability and stability of wheat in the Rio Grande do Sul State. Genet. Mol. Res. 16: 1-13. https://doi.org/10.4238/gmr16039735

Trugilho PF, Lima JT and Mori FA (2003).Correlaçãocanônica das características químicas e físicas da madeira de clones de Eucalyptusgrandise, Eucalyptussaligna. Rev.Cerne. 9: 66-80.

Trugilho PF, Lima JT, Mori FA, Lino AL. (2001).Avaliação de clones de Eucalyptus para produção de carvão vegetal. Rev. Cerne. 7: 104-114.

Vasconcelos ES, Cruz CD, Bhering LL, Resende J, et al. (2007).Métodoalternativo para análise de agrupamento. Pesq.Agrop.Bras.42: 1421-1428. http://dx.doi.org/10.1590/S0100-204X2007001000008 